across the Gulf. Some birds, as, for instance, the American redstart (Setophaga ruticilla), cross on a front of more than 2000 miles from east to west. Others again cross on a narrow front, as in the case of the red-breasted grosbeak (Zamelodia ludoviciana), which, although the breeding range has a width of 2500 miles from east to west, converge, until they leave the United States along a line of Gulf coast only 800 miles wide.

One of the most interesting of the species treated of in this work is the bobolink (Dolichonyx oryzivorus). Our author tells us that "in the case of the bobolink the evolution of a new extension of the migration route is now occurring before our very eyes. nature a lover of damp meadows, the bobolink was formerly cut off from the western States by the intervening arid region. But with the advent of irrigation and the bringing of large areas under cultivation, little colonies of nesting bobolinks are beginning to appear here and there almost to the Pacific," an excellent demonstration of the intimate relation between ecological conditions and geographical distribution. These individuals are stated to "return over the old route and show no disposition to shorten the flight by direct trip across New Mexico to the Gulf coast of 'Texas." The author, however, like many other writers on this subject, seems too prone to believe that most birds that pass are necessarily recorded. This, however, is absolutely impossible, even on a small and confined space; how much more so on a great continent such as America? The remarks on the red-eyed vireo (Vireosylva olivacea) as an example of a recent extension of breeding range and consequent elongation of migration route are of much interest. The extraordinary overseas flight of the American golden plover (Charadrius dominicus) in autumn is also referred to, as well as the curious elliptical form its migration takes at that season, the spring route being quite different from that of the autumn. Another most interesting and less known example of an elliptical migration route is that of the white-winged scoter (Oidemia deglandi), of which a full description and map are given. Mr. Cooke also directs attention to relative speed of various species on northward migration; as an example of slow and uniform migration he instances the black and white warbler (Mniotilta varia), to which he assigns an average speed of twenty-five miles a day during its northward passage from Florida to its breeding places in south-eastern Canada. On the other hand, as an example of rapid migration, the grey-cheeked thrush (Hvlocichla aliciae) is instanced, this bird being allotted a speed of r 30 miles a day for its journey of approximately 4000 miles; in the last part of the route, however, the speed is much greater than in the Mississippi valley. Another point touched on is the condition in which birds arrive at the end of a long migration flight, and the conclusion arrived at is that birds are not exhausted by their aerial journeys. This is, no doubt, largely the case in the western hemisphere, where the migratory movements are mainly performed overland from the equator to the Arctic regions; but in the Old World, especially in the British Isles, the migrants arriving after overseas flights often suffer much from exhaustion, even when the journey has been accomplished under the most favourable weather conditions. In this and in other respects, Mr. Cooke's work affords interesting comparisons between migration phenomena as observed in North America and in the British Isles.

Our author believes that food supply is the primary cause of migration; he says the "conclusion is inevitable that the advantages of the United States and Canada as a summer home, and the superb conditions of climate and food for the successful rearing of a nestful of voracious young, far overbalance the hazards and disasters of the journey thither. For these periodical trips did not just happen in their present form; each migration route, however long and complex, is but the present stage in development of a flight that at first was short, easily accomplished, and free from danger. Each lengthening of the course was adopted permanently, only after experience through many generations had proved its advantages," a sound statement, and one that is often in danger of being forgotten. Many other important points are dealt with in $\mathrm{Mr}$. Cooke's pamphlet, but enough has been said to indicate its comprehensive and valuable nature: it should be read by all who are interested in the subject.

W. E. C.

\section{SOLVENTS AND SOLUTIONS. ${ }^{1}$}

$T H E$ appearance of each volume published by the Carnegie Institution of Washington induces in us a feeling of envy towards our American confrères on account of the facilities thereby afforded to them for the publication in collected form of the results of investigations which otherwise would appear only in small instalments and scattered throughout the various volumes of scientific journals. Through the appearance in such a collected form of the results obtained in a series of investigations bearing on one main question, it becomes possible for other scientific workers to realise more clearly the actual extent of the advance made. For such publications as the present, therefore. all workers on solutions will be grateful.

The present monograph deals with a wide variety of subjects, nearly all of them, however, suggested by the solvate theory of solution so familiarly associated with the name of the chief author of this publication.

In the ten chapters into which the discussion is subdivided, we find the following subjects dealt with :Viscosities of solutions of cæsium salts in mixed solvents; conductivities of formamide solutions; radiometric measurements of the ionisation constants of indicators; influence of salts on the velocity of saponification and on the hydration of acetic anhydride; conductivity of organic acids in ethyl alcohol; conductivities and dissociation of some rather unusual salts in aqueous solution; the dissociating powers of free and of combined water; the absorption of potassium from aqueous solutions of potassium chloride.

Of the different contributions, the most interesting are, perhaps, the two dealing with the radio-metric measurements of the ionisation constants of indicators. By means of a grating and a radio-micrometer, of which a description is given, the light transmitted by solutions of methyl-orange and of rosolic acid have been determined. From these determinations the ionisation constants of the indicators could be calculated. In view of the excellent apparatus which the authors possess, further valuable work on a difficult problem may be hopefully expected.

A. F.

\section{THE FRUITS, PROSPECTS, AND LESSONS}

\section{OF RECENT BIOLOGICAL RESEARCH.}

$T \mathrm{HE}$ general welfare of mankind has been wonderfully promoted during the past 150 years by the rapid progress of chemical, physical, and biological science. In the early third of that period, physics and chemistry and their applications seem to have played the most active parts in promoting human welfare, although pure botany and zoology enlisted

I "Conductivities and Viscosities in Pure and in Mixed Solvents. Radio metric Measurements of the Ionisation Constants of Ind cators." By H.C Jones and Collaborators. Publication No. 230. (Washington D.C. Carnegie Institution, 1915.)

2 Presidential address delivered to the American Association for the Advancement of Science at Columbus, Ohio, on December 27, 1915, by Dr. Charles W. Eliot. 